\title{
Editorial: Microbial Role in the Carbon Cycle in Tropical Inland Aquatic Ecosystems
}

\author{
André M. Amado ${ }^{1,2 *}$ and Fábio Roland ${ }^{2}$ \\ ${ }^{1}$ Limnology Laboratory, Department of Oceanography and Limnology, Universidade Federal do Rio Grande do Norte, Rio \\ Grande do Norte, Brazil, ${ }^{2}$ Aquatic Ecology Laboratory, Department of Biology, Universidade Federal de Juiz de Fora, Minas \\ Gerais, Brazil
}

Keywords: metabolism, lakes, lagoons, rivers, latitudinal gradients, microorganisms, plankton, microbial ecology

\section{Editorial on the Research Topic}

\section{Microbial Role in the Carbon Cycle in Tropical Inland Aquatic Ecosystems}

\section{OPEN ACCESS}

Edited by:

Hongyue Dang,

Xiamen University, China

Reviewed by:

Ryan J. Newton,

University of Wisconsin-Milwaukee,

USA

*Correspondence: André M. Amado amado@ufrnet.br;

andre.amado@gmail.com

Specialty section: This article was submitted to

Aquatic Microbiology, a section of the journal

Frontiers in Microbiology

Received: 05 September 2016 Accepted: 04 January 2017

Published: 19 January 2017

Citation: Amado AM and Roland F (2017) Editorial: Microbial Role in the Carbon Cycle in Tropical Inland Aquatic

Ecosystems. Front. Microbiol. 8:20. doi: 10.3389/fmicb.2017.00020
Microorganisms have been recognized as central to nutrient mineralization and recycling in aquatic ecosystems since Lindeman's groundbreaking work on the trophic-dynamic aspect of ecology (Lindeman, 1942). Since the seventies, the development of new analytical technologies led to important conceptual perspectives, such as the microbial loop and the microbial food web (as summarized elsewhere, e.g., Cotner and Biddanda, 2002; Weisse, 2004), which have been important to understanding connections between microbially-mediated allochthonous and autochthonous organic matter decomposition and carbon dioxide $\left(\mathrm{CO}_{2}\right)$ concentrations and fluxes to the atmosphere (e.g., Cole et al., 2007; Berggren et al., 2012; Fonte et al., 2013). Currently, one of the main foci of microbial ecologists is to open the "microbial playbill" so that we can better understand who is doing "what" and "when" in ecosystem "plays" (Logue et al., 2015).

It is well-documented how seasonal variation of temperature, light incidence, and precipitation affects microbial metabolism (e.g., Simon and Rosenstock, 1992; Berggren et al., 2010) in high latitude ecosystems. Considering that temperature and light incidence are less variable and remain high year-round in the tropics (Lewis, 1996), one could expect differences in metabolic processes among the latitudinal regions (Farjalla et al., 2009) and consequent effects on microbial respiration and carbon emissions (essentially $\mathrm{CO}_{2}$ and methane) to the atmosphere. On the one hand, more intense metabolic processes are expected in lower latitudes. On the other hand, regional (e.g., flood pulse) or local (e.g., landscape characteristics) environmental conditions could be more relevant regulators of microbial metabolism than global factors (e.g., temperature, etc.). For instance, small rather than large planktonic organisms predominate at the base of microbial food webs of tropical aquatic ecosystems (i.e., pico- vs. nano-plankton) in comparison to temperate lakes, which typically means a higher flow of carbon through the microbes in the tropics than in temperate regions (Roland et al., 2010; Sarmento, 2012). Yet, certainly several new microbial ecology fundamentals will arise from asking questions that remain poorly understood, such as: (1) Does the current knowledge derived mostly from temperate ecosystems hold for tropical ecosystems? and (2) Can tropical ecosystems be good models to predict the changes in microbial metabolism and carbon cycling in temperate aquatic systems in light of climate warming scenarios?

The aim of this research topic-Microbial role in the carbon cycle in tropical inland aquatic ecosystems - was to provide a selection of studies that look at the wide variety of aspects of tropical microbial ecology including barely covered outlines (such as viruses-bacteria interactions or hydrodynamic events driven microbial communities) and their role to the carbon cycle. This research topic has documented 13 contributions that advance our knowledge on the microbial 
responses to natural latitudinal gradients, spatial and temporal patterns within and between ecosystems, and temperature and nutrient effects on microbial processes in the water and in the sediment. In order to better compile the information, the contributions were grouped in the following paragraphs as: (a) how physical and chemical variables (e.g., temperature and nutrients) affect carbon metabolism via microbes; (b) how latitudinal variation affects metabolism in the microbial food web components, and (c) how changes in environmental forces (such as flood pulse) affect microbial interactions.

Two meta-analysis studies focused on bacterial metabolism and top-down control and how they vary across latitudinal gradients. One study demonstrated that bacterial biomass production (BP) and respiration (BR) are higher while bacterial growth efficiency (BGE) is lower in the tropics (Amado et al.). Additionally, the other study demonstrated that bacterial and heterotrophic flagellate (HNF) abundance were lower in tropical than in temperate ecosystems (Segovia et al.). Furthermore, the authors still showed that the coupling between predator and prey did not differ between tropical and temperate zones, suggesting that other factors, such as the higher temperature or even HNF top-down control could be responsible for higher bacterial loss rates in the tropics.

One study that manipulated temperature and nutrients in tropical humic coastal lagoons (Scofield et al.) recorded increased $\mathrm{BR}$ and decreased BP and BGE with increasing temperature, confirming the results reported by Amado et al., and showing that temperature can be a valuable carbon metabolism predictor on a regional scale. Similarly, nutrient manipulations resulted in different metabolic responses and $\mathrm{CO}_{2}$ saturation patterns among lagoons, indicating that temperature effects are modified by local ecosystem conditions (Peixoto et al.). Additionally, another study performed in an eutrophic reservoir (Almeida et al.), observed net heterotrophy, net $\mathrm{CO}_{2}$ emission, and high ebullition and diffusive methane $\left(\mathrm{CH}_{4}\right)$ emissions. Despite high primary production rates, the shallow nature of the ecosystem, the high temperatures, and accumulated organic matter contributed to high decomposition rates. These three studies supported the idea that local factors are strong drivers of aquatic carbon metabolism at low latitudes.

The Amazon River basin is inserted in a low-latitude zone and it is recognized as a hotspot for freshwater $\mathrm{CO}_{2}$ emissions globally (Raymond et al., 2013; Abril et al., 2014). The flood pulse is the major ecological force affecting carbon-related processes and organisms in this region (Amado et al., 2006; Melack and Coe, 2012). Indeed, the flood pulse was the main driver for bacterial metabolism and carbon mobilization in rivers due to changes in the organic matter origin and quality (Vidal et al.). Moreover, one study in floodplain lakes of a large Amazon tributary contained bacterial and viral abundances that increased with increasing distance from the Amazon River (Almeida et al.). The longitudinal gradient was attributed to a backwater effect caused by the Amazon River that increased water turbidity and decreased organic carbon quality (availability) and concentration in the floodplain lakes downstream, which might also reduce the carbon flow through to the microbial food web.

Three studies evidenced that there is a great deal of heterogeneity among coastal lakes in the subtropical region.
One study using seasonal and diel approaches in a coastal lagoon in southern Brazil (Peri Lagoon, Santa Catarina state), showed that precipitation and temperature, as well as bacterial abundance were the main regulators of $\mathrm{CO}_{2}$ concentration in the water (Schmitz Fontes et al.). On the other hand, the bacterial community and activity in another coastal subtropical lagoon (Laguna de Rocha, Uruguay), was carbon-limited and was mainly driven by organic matter inputs from the watershed or dilutions by the seawater (Alonso et al.). This resulted in shifts in the microbial community and the microbial food web through HNF and virus increase. In addition, the dominance of wetlands and aquatic macrophytes reduced microbial carbon metabolism and $\mathrm{CO}_{2}$ concentration in the water when compared to the pelagic areas (i.e., higher depths and no macrophytes presence) creating heterogeneous conditions to carbon processing within the lake in a subtropical coastal lagoon in southern Brazil (Lake Mangueira, Rio Grande do Sul state; They et al.). Subtropical lakes are somewhat of a transition type of ecosystem, which consistently share regulation of microbial and carbon processes by local/regional environmental factors with tropical ecosystems, and by climate-driven seasonal environmental factors with temperate ecosystems.

Sediment metabolism has been extensively demonstrated to be relevant to the carbon balance in deep temperate lakes (e.g., Jonsson et al., 2001), but was poorly studied in tropical inland waters. Cardoso et al. observed high mineralization rates in the sediment of a mesotrophic tropical hydroelectric reservoir, which has driven the $\mathrm{CO}_{2}$ variation in the water column and high internal spatial variation in the respiration. Also, Canterle et al. observed both spatial and temporal variation in the microbial $\mathrm{CO}_{2}$ and $\mathrm{CH}_{4}$ production and emission in the sediment of a subtropical shallow wetland ecosystem. Additionally, Liengaard et al. detected high emission of nitrous oxide $\left(\mathrm{N}_{2} \mathrm{O}\right)$ in the largest wetland in the world (Pantanal, a pristine tropical wetland) providing up to $1.7 \%$ of global $\mathrm{N}_{2} \mathrm{O}$ emissions, as result of high organic matter availability processed via anaerobic metabolism. These findings are especially relevant taking the climate warming scenario. The intensification of biological processes may increase greenhouse-gas emissions 2-4 times more in the tropics than in temperate sediments (Marotta et al., 2014).

The articles presented in this research topic investigate several aspects of microbial interaction with carbon cycling in tropical inland waters and produced some evidence that it can change across the latitudinal gradient as follows: (a) higher temperature in the tropics enhances bacterial carbon processing and reduces BGE; (b) the energy flow through the microbial food web in the tropics may be either reduced due to low BGE, or enhanced due to a possible high top-down control of HNF; and (c) as in temperate ecosystems it seems consistent that nutrient availability is also a key component of the aquatic metabolism and carbon processing in tropical ecosystems, but local or regional regulation may frequently be equally or even more relevant than globally controlled environmental factors. Nonetheless, several gaps still remain. For example, is absolutely pertinent a better understanding regarding the controls of trophic cascade relationships (e.g., top-down control of bacteria by HNF) in the microbial food 
web and how landscape conditions (e.g., land use) affect carbon processing in aquatic ecosystems. Certainly, many opportunities exist for research focusing on the relationship of carbon and the microbial components of freshwater. As we commented before, we expect that these papers will stimulate new discussions and investigations to cover the great diversity of ecological processes that still need to be addressed and help formulate more robust general patterns for tropical freshwaters.

\section{AUTHOR CONTRIBUTIONS}

All authors listed, have made substantial, direct and intellectual contribution to the work, and approved it for publication.

\section{REFERENCES}

Abril, G., Martinez, J. M., Artigas, L. F., Moreira-Turcq, P., Benedetti, M. F., Vidal, L., et al. (2014). Amazon River carbon dioxide outgassing fuelled by wetlands. Nature 505, 395-398. doi: 10.1038/nature 12797

Amado, A. M., Farjalla, V. F., Esteves Fde, A., Bozelli, R. L., Roland, F., and Enrich-Prast, A. (2006). Complementary pathways of dissolved organic carbon removal pathways in clear-water Amazonian ecosystems: photochemical degradation and bacterial uptake. FEMS Microbiol. Ecol. 56, 8-17. doi: 10.1111/j.1574-6941.2006.00028.x

Berggren, M., Lapierre, J. F., and del Giorgio, P. A. (2012). Magnitude and regulation of bacterioplankton respiratory quotient across freshwater environmental gradients. Isme J. 6, 984-993. doi: 10.1038/ismej.2011.157

Berggren, M., Laudon, H., Jonsson, A., and Jansson, M. (2010). Nutrients constraints on metabolism affect the temperature regulation of aquatic bacterial growth efficiency. Microb. Ecol. 60, 894-902. doi: 10.1007/s00248-0109751-1

Cole, J. J., Prairie, Y. T., Caraco, N. F., Mcdowell, W. H., Tranvik, L. J., Striegl, R. G., et al. (2007). Plumbing the global carbon cycle: integrating inland waters into the terrestrial carbon budget. Ecosystems 10, 171-184. doi: 10.1007/s10021-006-9013-8

Cotner, J. B., and Biddanda, B. A. (2002). Small players, large role: microbial influence on biogeochemical processes in pelagic aquatic ecosystems. Ecosystems 5, 105-121. doi: 10.1007/s10021-001-0059-3

Farjalla, V. F., Amado, A. M., Suhett, A. L., and Meirelles-Pereira, F. (2009). DOC removal paradigms in highly humic aquatic ecosystems. Environ. Sci. Pollut. Res. Int. 16, 531-538. doi: 10.1007/s11356-009-0165-x

Fonte, E. S., Amado, A. M., Meirelles-Pereira, F., Esteves, F. A., Rosado, A. S., and Farjalla, V. F. (2013). The combination of different carbon sources enhances bacterial growth efficiency in aquatic ecosystems. Microb. Ecol. 66, 871-878. doi: 10.1007/s00248-013-0277-1

Jonsson, A., Meili, M., Bergstrom, A. K., and Jansson, M. (2001). Whole-lake mineralization of allochthonous and autochthonous organic carbon in a large humic lake (Ortrasket, N. Sweden). Limnol. Oceanogr. 46, 1691-1700. doi: $10.4319 /$ lo.2001.46.7.1691

Lewis, W. M. Jr. (1996). "Tropical lakes: how latitude makes a difference," in Perpectives in Tropical Limnology, eds F. Schiemer and K. T. Boland (Amsterdan: SPB Academic Publishing), 43-64.

\section{FUNDING}

This research topic received support from National Council of Technological and Scientific Development (CNPq-Brazil) specifically to AA under the grant \# 475537/2012-2 and to FR under the grant \# 309180/2013-9.

\section{ACKNOWLEDGMENTS}

We are grateful to the editorial staff at Frontiers in Microbiology for the invitation and support to this research topic. We thank R. Almeida, N. Barros, and J. Cotner and the reviewer for valuable comments on the manuscript.

Lindeman, R. L. (1942). The trophic-dynamic aspect of ecology. Ecology 23, 399-417. doi: 10.2307/1930126

Logue, J. B., Findlay, S. E., and Comte, J. (2015). Editorial: Microbial responses to environmental changes. Front. Microbiol. 6:1364. doi: 10.3389/fmicb. 2015.01364

Marotta, H., Pinho, L., Gudasz, C., Bastviken, D., Tranvik, L., and Enrich-Prast, A. (2014). Greenhouse gas production in low-latitude lake sediments responds strongly to arming. Nat. Clim. Change 4, 467-470. doi: 10.1038/nclimate2222

Melack, J. M., and Coe, M. T. (2012). "Climate change and the floodplain lakes of the Amazon Basin," in Climatic Change and Global Warming of Inland Waters (Chichester: John Wiley \& Sons, Ltd.), 295-310. doi: 10.1002/9781118470596.ch17

Raymond, P. A., Hartmann, J., Lauerwald, R., Sobek, S., Mcdonald, C., Hoover, M., et al. (2013). Global carbon dioxide emissions from inland waters. Nature 503, 355-359. doi: 10.1038/nature12760

Roland, F., Lobão, L. M., Vidal, L. O., Jeppesen, E., Paranhos, R., and Cole, J. (2010). Relationships between pelagic bacteria and phytoplankton abundances in contrasting tropical freshwaters. Aquat. Microb. Ecol. 60, 261-271. doi: 10.3354/ame01429

Sarmento, H. (2012). New paradigms in tropical limnology: the importance of the microbial food web. Hydrobiologia 686, 1-14. doi: 10.1007/s10750-012-1011-6

Simon, M., and Rosenstock, B. (1992). Carbon and nitrogen-sources of planktonic bacteria in lake constance studied by the composition and isotope-dilution of intracellular amino-acids. Limnol. Oceanogr. 37, 1496-1511. doi: 10.4319/lo.1992.37.7.1496

Weisse, T. (2004). "Pelagic microbes-protozoa and the microbial food web," in The Lakes Handbook: Limnology and Limnetic Ecology, eds P. O'sullivan and C. S. Reynolds (Malden, MA: Wiley-Blackwell), 417-460.

Conflict of Interest Statement: The authors declare that the research was conducted in the absence of any commercial or financial relationships that could be construed as a potential conflict of interest.

Copyright (c) 2017 Amado and Roland. This is an open-access article distributed under the terms of the Creative Commons Attribution License (CC BY). The use, distribution or reproduction in other forums is permitted, provided the original author(s) or licensor are credited and that the original publication in this journal is cited, in accordance with accepted academic practice. No use, distribution or reproduction is permitted which does not comply with these terms. 